Short communication

\title{
Isolation and radiocarbon analysis of elemental carbon in atmospheric aerosols using hydropyrolysis
}

\author{
Xiangyun Zhang ${ }^{\mathrm{a}, \mathrm{e}}$, Jun $\mathrm{Li}^{\mathrm{a}}{ }^{\text {,* }}$, Yangzhi Mo ${ }^{\mathrm{a}, \mathrm{e}}$, Chengde Shen ${ }^{\mathrm{b}}$, Ping Ding ${ }^{\mathrm{b}}$, Ning Wang ${ }^{\mathrm{b}}$, \\ Sanyuan Zhu ${ }^{a}$, Zhineng Cheng ${ }^{\mathrm{a}}$, Jiazhuo He ${ }^{\mathrm{a}}$, Yankuan Tian ${ }^{\mathrm{a}}$, Shutao Gao ${ }^{\mathrm{a}}$, Qin Zhou ${ }^{\mathrm{a}}$, \\ Chongguo Tian ${ }^{\mathrm{c}}$, Yingjun Chen ${ }^{\mathrm{d}}$, Gan Zhang ${ }^{\mathrm{a}, * *}$ \\ ${ }^{a}$ State Key Laboratory of Organic Geochemistry, Guangzhou Institute of Geochemistry, Chinese Academy of Sciences, Guangzhou, 510640, China \\ ${ }^{\mathrm{b}}$ State Key Laboratory of Isotope Geochemistry, Guangzhou Institute of Geochemistry, Chinese Academy of Sciences, Guangzhou, 510640, China \\ ${ }^{\mathrm{c}}$ Key Laboratory of Coastal Zone Environmental Processes and Ecological Remediation, Yantai Institute of Coastal Zone Research, Chinese Academy of Sciences, Yantai, \\ 264003, China \\ ${ }^{\mathrm{d}}$ College of Environmental Science and Engineering, Tongji University, Shanghai, 200092, China \\ e University of Chinese Academy of Sciences, Beijing, 100049, China
}

\section{G R A P H I C A L A B S T R A C T}

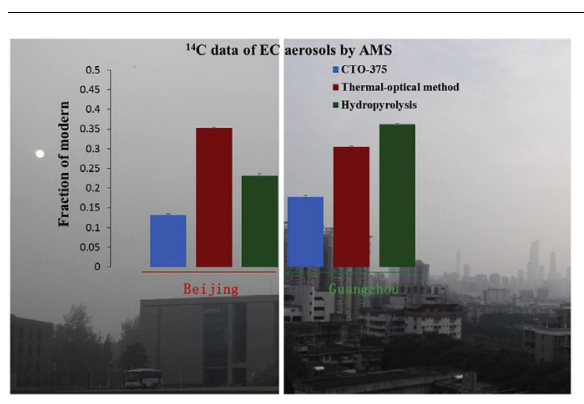

\section{A R T I C L E I N F O}

\section{Keywords:}

Elemental carbon

Atmospheric aerosols

Hydropyrolysis

Radiocarbon

\begin{abstract}
A B S T R A C T
Radiocarbon $\left({ }^{14} \mathrm{C}\right)$ analysis is a powerful tool that can unambiguously distinguish fossil and non-fossil sources of carbonaceous particles. However, one of the big challenges of this method is to isolate elemental carbon (EC) or black carbon (BC) for ${ }^{14} \mathrm{C}$ analysis. Hydropyrolysis (hypy) has proven to be an effective method for separating BC in environmental matrices. The potential of hypy for isolation of EC from atmospheric aerosols is evaluated using typical combustion products from non-fossil (biomass), fossil fuel (coal and petroleum), and ambient aerosol samples collected in Beijing and Guangzhou. Using solid state nuclear magnetic resonance (NMR) along with measurement of carbon content and ${ }^{14} \mathrm{C}$, hypy conditions of $15 \mathrm{MPa}$ hydrogen pressure and $550{ }^{\circ} \mathrm{C}$ temperature was confirmed to effectively separate EC from aerosol samples. Consequently, a comparison study of EC ${ }^{14} \mathrm{C}$ in aerosol samples separated using the two-step heating method (CTO-375), thermal-optical method and hypy was conducted. The results show that hypy is an effective and stable approach for matrix-independent ${ }^{14} \mathrm{C}$ quantification of EC in aerosols.
\end{abstract}

\footnotetext{
* Corresponding author.

** Corresponding author.

E-mail addresses: junli@gig.ac.cn (J. Li), zhanggan@gig.ac.cn (G. Zhang).
} 


\section{Introduction}

Elemental carbon (EC) or black carbon (BC) of carbonaceous aerosols (CAs) is derived from incomplete combustion of fossil fuels or biomass and is responsible for an overall warming effect due to either absorbing incoming solar radiation in the atmosphere or reducing the albedo of surface materials (i.e., snow and ice) (Fuzzi et al., 2006; Schwarz et al., 2015; Szidat, 2009; Szidat et al., 2004b, 2009). Therefore, detailed knowledge of the sources of EC is necessary for the implementation of mitigation strategies for their reduction.

Radiocarbon $\left({ }^{14} \mathrm{C}\right)$ analysis is a powerful tool for unambiguously distinguishing fossil and non-fossil sources of carbonaceous particles (Currie, 2000; Szidat, 2009; Szidat et al., 2006, 2009; Gustafsson et al., 2009; Kirillova et al., 2013; Liu et al., 2013; Pavuluri et al., 2013; Wang et al., 2013; Wozniak et al., 2012; Zencak et al., 2007a; Zhang et al., 2010). However, one of the big challenges of this method is to isolate elemental carbon (EC) for ${ }^{14} \mathrm{C}$ analysis. In 2013, a study showed the results from an intercomparison of 9 laboratories for ${ }^{14} \mathrm{C}$ analysis of carbonaceous aerosol samples. ${ }^{14} \mathrm{C}$ analysis of EC revealed a large deviation between the laboratories of $28-79 \%$ as a consequence of different separation techniques (Szidat et al., 2013). Results for the recovered EC mass concentration also showed poor agreement between two oxygen-based methods in the recent study (Zenker et al., 2017). Therefore, there is an urgent need to find an effective and stable approach to isolate $\mathrm{EC}$ for ${ }^{14} \mathrm{C}$ analysis, which approach is independent of laboratory, operator, and sample matrix.

Recently, hydropyrolysis (hypy) methods have been proposed to be an effective method for separating black carbon $\left(\mathrm{BC}_{\mathrm{hypy}}\right)$ in environmental matrices (Ascough et al., 2009; Meredith et al., 2012). However, the chemical structure of CAs differs by source sample and combustion temperature, and the content and stability of EC produced from these CAs vary (Wurster et al., 2012, 2013). Whether these differences affect the separation of EC via hypy, and whether hypy can be used to separate EC from CAs for ${ }^{14} \mathrm{C}$ analysis, remains unverified.

To verify the separation of EC from atmospheric aerosols for ${ }^{14} \mathrm{C}$ analysis via hypy, an experiment was conducted using typical combustion products and ambient aerosol samples under different hypy operating conditions. The objectives of this study were to evaluate the hypy method for separation and ${ }^{14} \mathrm{C}$ analysis of EC in aerosols, and to compare the ${ }^{14} \mathrm{C}$ results of aerosols separated using a two-step heating method (CTO-375), a thermal-optical method and hypy.

\section{Materials and methods}

\subsection{Sample collection}

Biomass burning, coal combustion and traffic emissions are the main sources of carbonaceous particles in China (Huang et al., 2014; Zhang et al., 2015b). Therefore, 7 smoke particle samples, including 3 typical biomass samples, 2 residential coal combustion samples and 2 vehicle exhaust particle samples were collected. Biomass burning emission samples, including wheat straw combustion (C4 plant), corn stem combustion (C3 plant) and pine wood combustion (woody plant), were collected through a sampling system (see details in the Supporting Information [SI], Fig. S1). Two different types of raw coal, chunks, sourced from Pingdingshan (PDS) in Henan province and Chongzhou (CZ) in Shandong province, were tested in this study. The characteristics of coal samples are summarized in Table S1 in the SI. Coal was combusted in a high-efficiency stove, and $\mathrm{PM}_{2.5}$ emissions were collected using a dilution sampling system, which has been described in detail previously (Chen et al., 2015; Wang et al., 2016). One type of gasoline truck and one type of diesel truck were used in this study. Fine exhaust particles were collected using the on-board emission measurement system (Fig. S2). A description of the on-board emission test system was provided in a previous report (Cui et al., 2017). A detailed description and schematic diagram of this system are given in the SI.
Two urban aerosol samples were selected, which were collected in Beijing and Guangzhou in the winter. All the $\mathrm{PM}_{2.5}$ samples were collected on pre-combusted quartz filters $(8 \times 10$ inch; Pall $)$ using a highvolume sampler equipped with a $\mathrm{PM}_{2.5}$ impactor (Xintuo Analytical Instruments, Shanghai, China). After sampling, all filters were wrapped in aluminum foil and stored at $-20^{\circ} \mathrm{C}$ until analysis.

\subsection{Hydropyrolysis}

Particles captured on the surface of quartz filters were peeled off with stainless steel tweezers. The particles, along with remnants of the filters, were ground into powder. A fraction of the powder was mixed fully with ammonium dioxydithiomolybdate $\left[\left(\mathrm{NH}_{4}\right)_{2} \mathrm{MoO}_{2} \mathrm{~S}_{2}\right]$ as a catalyst to reach a nominal molybdenum loading of $1 \%$ by weight. The mixture was vacuum dried and loaded into the quartz tube $(5 \mathrm{~mm}$ inner diameter, $40 \mathrm{~mm}$ long) for hypy. The hypy method has been described in published studies (Bishop et al., 1998; Meredith et al., 2012). Briefly, the samples were first heated in the reactor tube from ambient temperature to $250{ }^{\circ} \mathrm{C}$ at a rate of $300^{\circ} \mathrm{C} \mathrm{min}{ }^{-1}$, and then from $300{ }^{\circ} \mathrm{C}$ to the final temperature $\left(350{ }^{\circ} \mathrm{C}, 400{ }^{\circ} \mathrm{C}, 450{ }^{\circ} \mathrm{C}, 500{ }^{\circ} \mathrm{C}, 525^{\circ} \mathrm{C}, 550{ }^{\circ} \mathrm{C}\right)$ at $8^{\circ} \mathrm{C} \mathrm{min}^{-1}$, then held for $5 \mathrm{~min}$, under hydrogen pressure of $15 \mathrm{MPa}$ and a flow rate of $5.0 \mathrm{~L} / \mathrm{min}$. Blank experiments without samples were utilized to confirm that the hypy device (Meredith et al., 2012) (purchased from the University of Nottingham, Nottingham, UK) remained sufficiently clean throughout the experiment.

\subsection{NMR analysis}

All the ${ }^{13} \mathrm{C}$ solid state NMR experiments were performed using an AVANCE III 400-MHz NMR spectrometer (Bruker, Billerica, MA, USA). The selected samples were tested with direct-polarization/magic-anglespinning (DP/MAS) ${ }^{13} \mathrm{C}$ solid state NMR experiments (Mao and Schmidt-Rohr, 2004) and details of the method was described in the SI.

\section{4. ${ }^{14} \mathrm{C}$ analysis}

The ${ }^{14} \mathrm{C}$ analysis experiments were determined using a compact AMS instrument (NEC, National Electrostatics Corporation, USA) at the Guangzhou Institute of Geochemistry, CAS. The method of the ${ }^{14} \mathrm{C}$ analysis (Liu et al., 2013, 2017; Zhu et al., 2015a,b) is also described in the SI.

\section{Results and discussion}

\subsection{Purification of EC via hypy}

The seven types of common combustion products were collected for hypy experiments. Based on previous studies, significant further loss of carbon occurs via hydrogasification, predominately yielding methane when the hypy temperature is above $575^{\circ} \mathrm{C}$; this indicates the decomposition of BC (Ascough et al., 2009; Rocha et al., 1999). Therefore, final temperatures of $350{ }^{\circ} \mathrm{C}, 400{ }^{\circ} \mathrm{C}, 450{ }^{\circ} \mathrm{C}, 500{ }^{\circ} \mathrm{C}, 525^{\circ} \mathrm{C}$ and $550{ }^{\circ} \mathrm{C}$ were selected for hypy.

To monitor the stripping of non-elemental carbon, elemental analysis was used to determine the carbon content of hypy residue at each temperature and the measurement uncertainty of elemental analysis method was below 3\%. Fig. 1 shows carbon loss for all typical combustion samples over the $350-550{ }^{\circ} \mathrm{C}$ range, corresponding to the loss of labile (i.e., non- $\mathrm{EC}_{\text {hypy }}$ ) carbon from the aerosol organic matter. For all samples, a large proportion of the labile carbon was removed below $400{ }^{\circ} \mathrm{C}$, indicating that a major portion of the labile organic carbon (OC) in fuel combustion emissions could be stripped under hypy conditions at $400{ }^{\circ} \mathrm{C}$. However, the carbon contents of hypy residues from different fuel combustion aerosols showed differing results at temperatures above $400{ }^{\circ} \mathrm{C}$. For the two motor vehicle emission samples, about $67 \%$ and $80 \%$ of carbon was removed at $400{ }^{\circ} \mathrm{C}$, whereas less than $5 \%$ more 


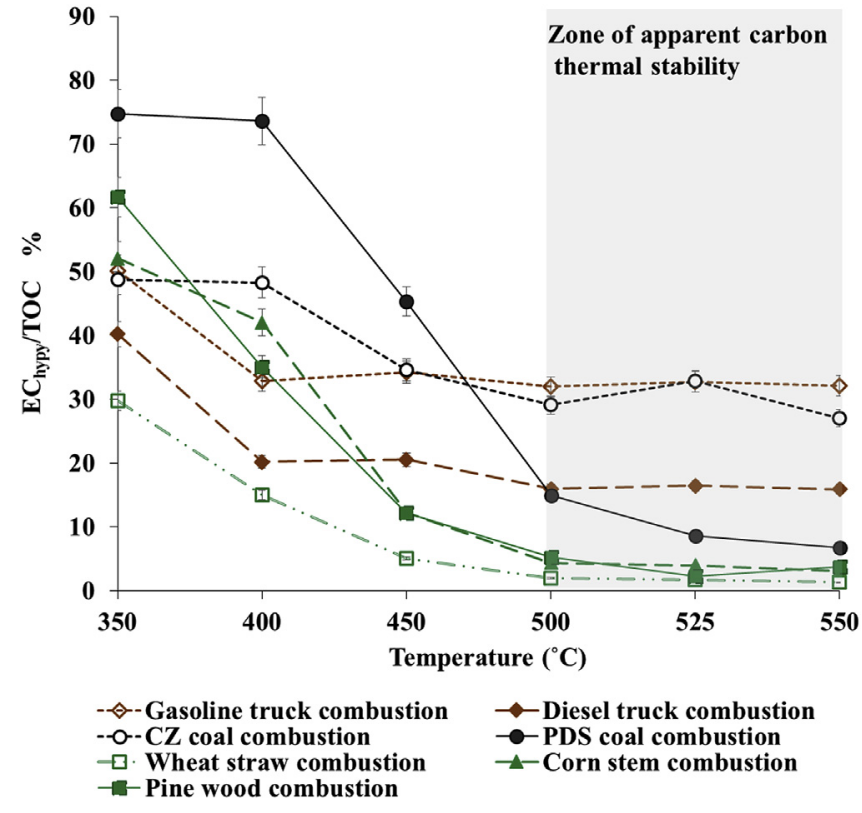

Fig. 1. Element carbon ( $\mathrm{EC}_{\text {hypy }}$ ) as a proportion of total organic carbon (TOC) measured for the residues of typical combustion products after hydropyrolysis (hypy) at different temperatures.

was stripped between 425 and $525^{\circ} \mathrm{C}$, and no further carbon loss was observed at $550{ }^{\circ} \mathrm{C}$. The curve of carbon loss from vehicle emission aerosols at temperatures over $400^{\circ} \mathrm{C}$ matched that of n-hexane soot (Meredith et al., 2012). This result implies that the refractory residue of vehicle emission aerosols has the same structure as that of n-hexane soot. Unlike vehicle emissions, the residual carbon from coal and biomass combustion aerosols decreased with increasing hypy temperature, with $9 \%-37 \%$ more carbon removed at $500{ }^{\circ} \mathrm{C}$, and then a relatively stable state was reached from $500{ }^{\circ} \mathrm{C}$ to $550^{\circ} \mathrm{C}$. The subsequent plateau in remaining carbon content between 500 and $550{ }^{\circ} \mathrm{C}$ represents a zone of apparent thermal stability when non-EC $\mathrm{E}_{\text {hypy }}$ organic matter (e.g., lignocellulosic material, humic acids, proteins and lipids) and relatively labile pyrogenic carbon have been removed, and thus the residual carbon represents the sample $\mathrm{EC}_{\text {hypy }}$ content, which is the portion of the EC continuum that is stable under hypy conditions. Differences in the carbon structures of the three types of typical combustion products may be responsible for their differing response to hypy conditions.

The ${ }^{13} \mathrm{C}$ solid state NMR spectroscopy can be used to illustrate carbon structural characteristics of the matrices, making it a good method for monitoring changes in carbonaceous functional groups caused by various hypy treatments (Ascough et al., 2010). The ${ }^{13} \mathrm{C}$ solid state NMR spectra of three typical combustion products (including gasoline truck combustion, coal combustion and corn stem combustion) subjected to various hypy temperatures are shown in Fig. S3. These NMR results show the content of aliphatic carbon decreases gradually with increasing hypy temperature. When the temperature reached $500{ }^{\circ} \mathrm{C}$, aliphatic carbon was almost completely removed from vehicle exhaust aerosols (Fig. 2). At $525^{\circ} \mathrm{C}$, aliphatic carbon was also stripped from coal and corn stem combustion samples. In all the samples, probably only aromatic carbon remained when the hypy temperature was $550^{\circ} \mathrm{C}$ (Fig. S3).

Two aerosol samples, collected in Beijing and Guangzhou, were also selected for hypy experiments. The carbon loss from both urban samples reached a plateau when the hypy temperature ranged from 500 to $550^{\circ} \mathrm{C}$ (Fig. 3 and Table S3). To verify the effect of the hypy experiment on ${ }^{14} \mathrm{C}$ results, all hypy experiment products for the two urban aerosol samples were tested using ${ }^{14} \mathrm{C}$-AMS. The ${ }^{14} \mathrm{C}$ contents of both urban aerosol samples remained stable over the range of $500-550{ }^{\circ} \mathrm{C}$ (Fig. 3). The differences of the highest and the lowest $f_{\mathrm{m}}$ values of the two urban aerosols over the stable range were 0.0064 and 0.0111 with little difference in their measurement uncertainty, respectively. Combined with the carbon content results of EC residues obtained through hypy treatment (Fig. 3), these results illustrate that the source and composition of the two urban aerosol samples are stable over the range of $500-550{ }^{\circ} \mathrm{C}$. This finding indicates that non-EC organic matter is effectively removed from the aerosol organic matter by hypy at $550{ }^{\circ} \mathrm{C}$.

\subsection{Radiocarbon comparison of EC via CTO-375, thermal-optical method and hypy}

On the one hand, radiocarbon measurement provides a unique tracer that can directly apportion EC into fossil and non-fossil fractions, while on the other hand, the EC fraction is not a single compound and it is nearly impossible to separate these mixtures completely with current technologies. Therefore, isolation of the purest possible carbon fractions of interest is recommended for ${ }^{14} \mathrm{C}$ determination. Thermal treatment is the most common method currently used to separate EC, and the key technical difficulty is obtaining a sufficient mass of pure carbon to represent the ${ }^{14} \mathrm{C}$ signal of the entirety of EC (Szidat et al., 2004c). Previous studies have significantly improved our knowledge of the sources of EC, yet critical challenges remain in achieving complete separation of EC, and correlating radioisotope signals and mass recovery of EC. First, a portion of the EC fraction, in particular non-refractory EC (char-EC), will be stripped with some OC under an oxidative atmosphere, and thus the CTO-375 method may harvest only the most refractory portion of EC (soot-EC) (Hammes et al., 2007; Zencak et al., 2007b). Second, it has long been recognized that a fraction of OC (e.g., sucrose) in ambient aerosols heated in an $\mathrm{O}_{2}$-free atmosphere will char to pyrolytic carbon (PyC) (Cadle et al., 1980), which has significantly different thermal and optical properties from OC that are similar to EC (Watson et al., 2005). When conducting the thermal-optical method, the formation of $\mathrm{PyC}$ is monitored via transmittance/reflectance of a visible laser during the $\mathrm{He}$ and $\mathrm{He} / \mathrm{O}_{2}$ heating phases, and the carbon evolved before the split line at which the laser signal returns to its initial level is defined as the OC fraction, while the carbon evolved after this line is considered the EC fraction (Birch and Cary, 1996; Chow et al., 1993). Therefore, the thermal-optical method has been widely used to separate OC from EC for radiocarbon analysis (Zhang et al., 2012, 2015a; Zotter et al., 2014; Liu et al., 2017). However, the ${ }^{14} \mathrm{C}$ results obtained by this method are affected by the thermodynamic heterogeneity, oxidability, and light-absorbing ability of the entire EC fraction in the ambient environment, as well as the fraction of EC isolated by the system (Liu et al., 2017; Zotter et al., 2014).

In this study, the modern EC fractions of two urban aerosol samples separated using the CTO-375 method, the thermal-optical method and hypy were compared (Fig. 4 and Table S4). There are many different heating methods used in conjunction with two-step heating system for EC/OC determination of radiocarbons (Calzolai et al., 2011; Lavanchy et al., 1999; Liu et al., 2013; Szidat et al., 2004c; Zhang et al., 2010). In this article, the two-step heating system (CTO-375) (Liu et al., 2013) and the thermo-optical method (Liu et al., 2017), were selected for separation of EC from aerosol samples, and details of these methods can be found in the literature (Liu et al., 2013, 2017). Fig. 4 shows the ${ }^{14} \mathrm{C}$ results of EC in the two urban aerosol samples. All ${ }^{14} \mathrm{C}$ values were reported as the $f_{\mathrm{m}}$ after correction for fractionation with $\delta^{13} \mathrm{C}$. In this study, $f_{\mathrm{m}}$ was converted into the fraction of contemporary carbon $\left(f_{\mathrm{c}}\right)$ to eliminate the effect of nuclear bomb tests using a conversion factor (Szidat et al., 2004a), which was $1.10 \pm 0.05$ for EC in 2013 (Liu et al., 2014).

The $f_{\mathrm{c}}$ results based on hypy show that the percentage of non-fossilderived sources was significantly higher in Guangzhou (36\%) than in Beijing (23\%), and this pattern and spatial trend was also seen previously (Andersson et al., 2015; Huang et al., 2014). Compared to hypy, the $f_{\mathrm{c}}$ values of the CTO-375 method are much lower. As discussed above, a portion of the EC fraction, especially non-refractory EC (char- 


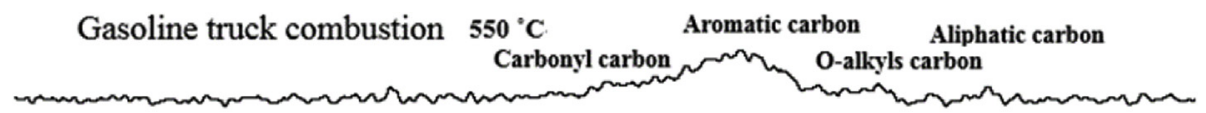

$525^{\circ} \mathrm{C}$

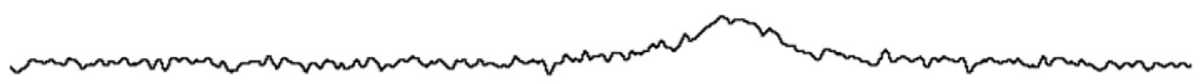

$500{ }^{\circ} \mathrm{C}$
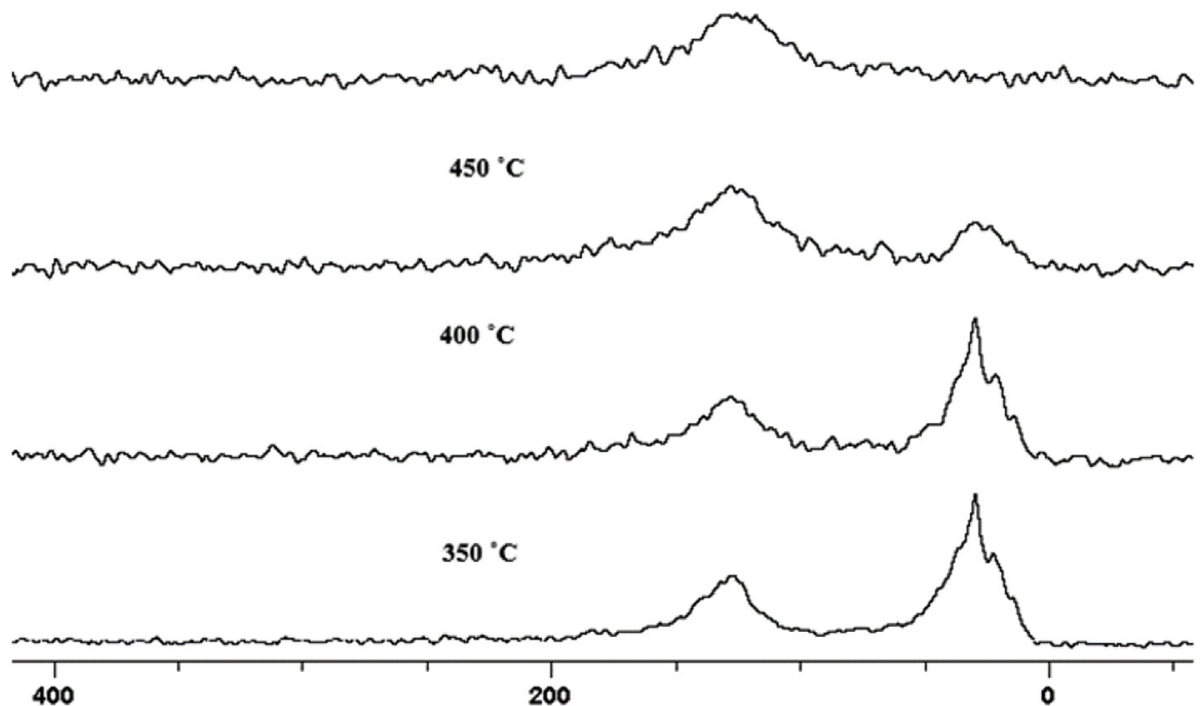

Fig. 2. ${ }^{13} \mathrm{C}$ solid state NMR spectra of the EC residues from the gasoline truck combustion samples following hypy treatment at $350{ }^{\circ} \mathrm{C}$ to $550{ }^{\circ} \mathrm{C}$.
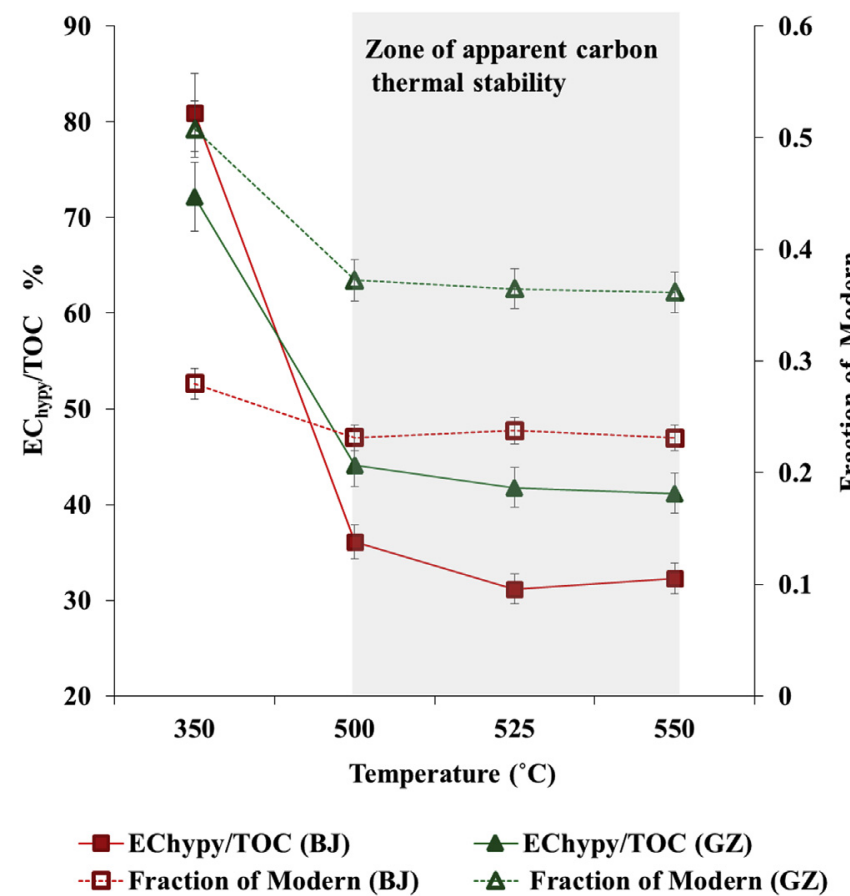

- EChypy/TOC (GZ)

$\triangle-$ Fraction of Modern (GZ)

Fig. 3. EC $_{\text {hypy }}$ as a proportion of TOC (left axis) and results of Radiocarbon $\left({ }^{14} \mathrm{C}\right)$ (right axis) measured for the residues from Beijing and Guangzhou after hypy at different temperatures.

EC), is over-burned with the CTO-375 method, and only the refractory part of EC (soot-EC) can be harvested (Hammes et al., 2007; Zencak et al., 2007b). This finding suggests that a large portion of EC from biomass burning was lost, along with some OC, in the oxidative atmosphere. Furthermore, samples with higher proportions of biomass combustion had higher $f_{\mathrm{c}}$ loss; for example, the Guangzhou sample lost $54 \%$, while the sample from Beijing lost $44 \%$. Unlike the trend of $f_{\mathrm{c}}$ results for hypy and the CTO-375 method, $f_{\mathrm{c}}$ results measured with the thermo-optical method indicated a larger biomass burning component in Beijing (35\%) than in Guangzhou (30\%). The value measured from Beijing was higher than those based on the hypy and CTO-375 methods, while the value from Guangzhou was comparable to that of hypy, but higher than that of the CTO-375 method.

The cause of the above results as shown in Fig. 4 is not very clear. But according to previous studies which have indicated predominant contributions (more than 75\%) of fossil fuel to EC in the Beijing winter (Zhang et al., 2015b), it could be speculated that this difference may arise from the analysis method itself. It is generally agreed that thermal conversion of biomass, and the resulting EC characteristics, are regulated primarily by the nature of the feedstock and heating temperature (Liu et al., 2015; Tripathi et al., 2016). In terms of heating temperature, the morphology of EC largely maintains the macrostructure of the feedstock during relatively low temperature pyrolysis, as lower treatment temperatures (usually $<\sim 300{ }^{\circ} \mathrm{C}$ ) are not sufficient to break down the cross-linkage between carbon atoms in the raw materials. With increasing treatment temperature, removal of simple molecules from outer surfaces of the feedstock could gradually enhance the development of the pore structure and surface area of EC. However, a high treatment temperature may also induce deformation and collapse of some fine pore structures (Lian et al., 2011; Lian and Xing, 2017). The carbonaceous components produced from biomass combustion at high temperature are more stable, and more difficult to separate from EC, than low-temperature products (Wurster et al., 2013). Biomass combustion in Beijing originates from cooking and heating in winter, which involve high temperatures, while the biomass emissions from Guangzhou originate primarily from natural emissions at lower temperatures (Huang et al., 2014; Zhu et al., 2015a,b). The large 


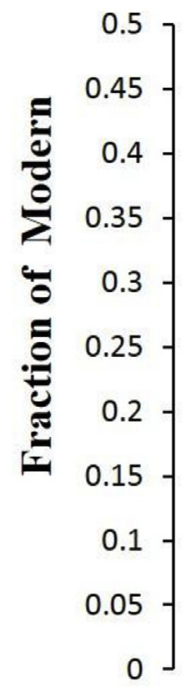

CTO-375

- Thermal-optical method

- Hydropyrolysis

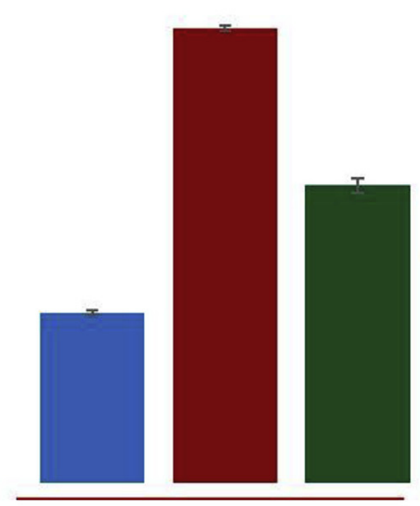

Beijing

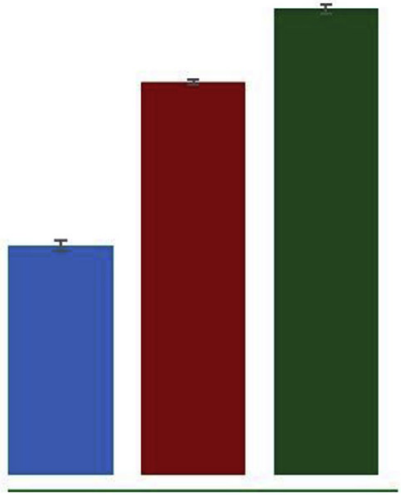

Guangzhou

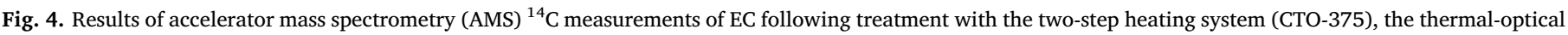
method and hydropyrolysis.

contributions from coal burning and biomass combustion in Beijing winter at high temperature may lead to a bias of EC separation determined through the thermal-optical method (Liu et al., 2017). Hypy, which is pyrolysis assisted by high hydrogen pressures (150 bar), facilitates the complete reductive removal of labile organic matter, thereby isolating a highly stable portion of $\mathrm{EC}_{\text {hypy }}$ and thus avoiding charring. This may lead to a different ${ }^{14} \mathrm{C}$ result of EC between thermaloptical method and the hypy. All the above causes may lead to the results as shown in Fig. 4.

\section{Conclusion}

To find an effective and stable approach to isolate EC from atmospheric aerosols for ${ }^{14} \mathrm{C}$ analysis, the potential of hypy was evaluated using typical combustion products and ambient aerosol samples. The ${ }^{13} \mathrm{C}$ solid state NMR spectra and carbon content results of three typical combustion products show that the content of aliphatic carbon decreases gradually with increasing hypy temperature. When the hypy temperature reached $550^{\circ} \mathrm{C}$, probably only aromatic carbon remained in the sample. The ${ }^{14} \mathrm{C}$ contents and carbon content results of both urban aerosol samples illustrate that the source and composition of the two urban aerosol samples are stable over the range of $500-550{ }^{\circ} \mathrm{C}$ through hypy treatment. This finding indicates that hypy conditions of $15 \mathrm{MPa}$ hydrogen pressure and $550{ }^{\circ} \mathrm{C}$ temperature was confirmed to effectively separate EC from aerosol samples.

Consequently, a comparison study of EC ${ }^{14} \mathrm{C}$ in ambient aerosol samples separated using the CTO-375 method, thermal-optical method and hypy was conducted. The $f c$ results based on hypy show that the percentage of non-fossil-derived sources was significantly higher in Guangzhou (36\%) than in Beijing (23\%). Compared to hypy, the $f c$ values of the CTO-375 method are much lower and the trend of ${ }^{14} \mathrm{C}$ results measured with the thermo-optical method is the opposite. Hypy, which is pyrolysis assisted by high hydrogen pressures (150 bar), facilitates the probably complete reductive removal of labile organic matter, thereby isolating a highly stable portion of $\mathrm{EC}_{\text {hypy }}$ and thus avoiding charring. Therefore, hypy is an effective and stable approach for matrix-independent ${ }^{14} \mathrm{C}$ quantification of EC in aerosols.

\section{Acknowledgments}

This study was supported by the National Natural Science Foundation of China (NSFC; Nos. 41430645 and 41473101), State Key Laboratory of Organic Geochemistry (SKLOGA201603A and SKLOGC201604) and Guangzhou Institute of Geochemistry, Chinese Academy of Sciences (GIG-GNKF201603). The authors are grateful to Dr. Jingdong Mao for assistance in the NMR experiments. All data in this manuscript are freely available upon request through the corresponding author (junli@gig.ac.cn). This is contribution No. IS-2605 from GIGCAS.

\section{Appendix A. Supplementary data}

Supplementary data to this article can be found online at https:// doi.org/10.1016/j.atmosenv.2018.11.005.

\section{References}

Andersson, A., Deng, J.J., Du, K., Zheng, M., Yan, C.Q., Skold, M., Gustafsson, O., 2015. Regionally-varying combustion sources of the January 2013 severe haze events over eastern China. Environ. Sci. Technol. 49 (4), 2038-2043.

Ascough, P.L., Bird, M.I., Brock, F., Higham, T.F.G., Meredith, W., Snape, C.E., Vane, C.H., 2009. Hydropyrolysis as a new tool for radiocarbon pre-treatment and the quantification of black carbon. Quat. Geochronol. 4 (2), 140-147.

Ascough, P.L., Bird, M.I., Meredith, W., Wood, R.E., Snape, C.E., Brock, F., Higham, T.F.G., Large, D.J., Apperley, D.C., 2010. Hydropyrolysis: implications for radiocarbon pretreatment and characterization of black carbon. Radiocarbon 52 (3), 1336-1350.

Birch, M.E., Cary, R.A., 1996. Elemental carbon-based method for monitoring occupational exposures to particulate diesel exhaust. Aerosol Sci. Technol. 25, 221-241.

Bishop, A.N., Love, G.D., McAulay, A.D., Snape, C.E., Farrimond, P., 1998. Release of kerogen-bound hopanoids by hydropyrolysis. Org. Geochem. 29 (4), 989-1001.

Cadle, S., Groblicki, P., Stroup, D., 1980. Uncertainties in charring correction in the analysis of elemental and organic carbon in atmospheric particles by thermal/optical methods. Anal. Chem. 52, 2201-2206.

Calzolai, G., Bernardoni, V., Chiari, M., Fedi, M.E., Lucarelli, F., Nava, S., Riccobono, F., Taccetti, F., Valli, G., Vecchi, R., 2011. The new sample preparation line for radiocarbon measurements on atmospheric aerosol at LABEC. Nucl. Instrum. Methods Phys. Res. Sect. B Beam Interact. Mater. Atoms 269 (3), 203-208.

Chen, Y., Zhi, G., Feng, Y., Chongguo, T., Bi, X., Li, J., Zhang, G., 2015. Increase in polycyclic aromatic hydrocarbon (PAH) emissions due to briquetting: a challenge to the coal briquetting policy. Environ. Pollut. 204, 58-63.

Chow, J.C., Watson, J.G., Pritchett, L.C., Pierson, W.R., Frazier, C.A., Purcell, R.G., 1993. The dri thermal/optical reflectance carbon analysis system: description, evaluation and applications in U.S. Air quality studies. Atmos. Environ. Part A. General Topics 27 (8), 1185-1201. 
Cui, M., Chen, Y., Feng, Y., Li, C., Zheng, J., Tian, C., Yan, C., Zheng, M., 2017. Measurement of PM and its chemical composition in real-world emissions from nonroad and on-road diesel vehicles. Atmos. Chem. Phys. 17 (11), 6779-6795.

Currie, L.A., 2000. Evolution and multidisciplinary frontiers of C-14 aerosol science. Radiocarbon 42 (1), 115-126.

Fuzzi, S., Andreae, M.O., Huebert, B.J., Kulmala, M., Bond, T.C., Boy, M., Doherty, S.J., Guenther, A., Kanakidou, M., Kawamura, K., Kerminen, V.M., Lohmann, U., Russell, L.M., Poschl, U., 2006. Critical assessment of the current state of scientific knowledge, terminology, and research needs concerning the role of organic aerosols in the atmosphere, climate, and global change. Atmos. Chem. Phys. 6, 2017-2038.

Gustafsson, O., Krusa, M., Zencak, Z., Sheesley, R.J., Granat, L., Engstrom, E., Praveen, P.S., Rao, P.S.P., Leck, C., Rodhe, H., 2009. Brown clouds over south Asia: biomass or fossil fuel combustion? Science 323 (5913), 495-498.

Hammes, K., Schmidt, M.W.I., Smernik, R.J., Currie, L.A., Ball, W.P., Nguyen, T.H., Louchouarn, P., Houel, S., Gustafsson, Ö., Elmquist, M., Cornelissen, G., Skjemstad, J.O., Masiello, C.A., Song, J., Peng, P.a., Mitra, S., Dunn, J.C., Hatcher, P.G., Hockaday, W.C., Smith, D.M., Hartkopf-Fröder, C., Böhmer, A., Lüer, B., Huebert, B.J., Amelung, W., Brodowski, S., Huang, L., Zhang, W., Gschwend, P.M., FloresCervantes, D.X., Largeau, C., Rouzaud, J.-N., Rumpel, C., Guggenberger, G., Kaiser, K., Rodionov, A., Gonzalez-Vila, F.J., Gonzalez-Perez, J.A., de la Rosa, J.M., Manning, D.A.C., López-Capél, E., Ding, L., 2007. Comparison of quantification methods to measure fire-derived (black/elemental) carbon in soils and sediments using reference materials from soil, water, sediment and the atmosphere. Global Biogeochem. Cycles 21 (3), GB3016.

Huang, R.J., Zhang, Y.L., Bozzetti, C., Ho, K.F., Cao, J.J., Han, Y.M., Daellenbach, K.R., Slowik, J.G., Platt, S.M., Canonaco, F., Zotter, P., Wolf, R., Pieber, S.M., Bruns, E.A., Crippa, M., Ciarelli, G., Piazzalunga, A., Schwikowski, M., Abbaszade, G., SchnelleKreis, J., Zimmermann, R., An, Z.S., Szidat, S., Baltensperger, U., El Haddad, I., Prevot, A.S.H., 2014. High secondary aerosol contribution to particulate pollution during haze events in China. Nature 514 (7521), 218-222.

Kirillova, E.N., Andersson, A., Sheesley, R.J., Krusa, M., Praveen, P.S., Budhavant, K., Safai, P.D., Rao, P.S.P., Gustafsson, O., 2013. C-13- and C-14-based study of sources and atmospheric processing of water-soluble organic carbon (WSOC) in South Asian aerosols. J. Geophys. Res. Atmos. 118 (2), 614-626.

Lavanchy, V.M.H., Gaggeler, H.W., Nyeki, S., Baltensperger, U., 1999. Elemental carbon (EC) and black carbon (BC) measurements with a thermal method and an aethalometer at the high-alpine research station Jungfraujoch. Atmos. Environ. 33 (17), 2759-2769.

Lian, F., Huang, F., Chen, W., Xing, B.S., Zhu, L.Y., 2011. Sorption of apolar and polar organic contaminants by waste tire rubber and its chars in single- and bi-solute systems. Environ. Pollut. 159 (4), 850-857.

Lian, F., Xing, B.S., 2017. Black carbon (biochar) in water/soil environments: molecular structure, sorption, stability, and potential risk. Environ. Sci. Technol. 51 (23), 13517-13532.

Liu, D., Li, J., Zhang, Y.L., Xu, Y., Liu, X., Ding, P., Shen, C.D., Chen, Y.J., Tian, C.G., Zhang, G., 2013. The use of levoglucosan and radiocarbon for source apportionment of PM2.5 carbonaceous aerosols at a background site in East China. Environ. Sci. Technol. 47 (18), 10454-10461.

Liu, J., Li, J., Zhang, Y., Liu, D., Ding, P., Shen, C., Shen, K., He, Q., Ding, X., Wang, X., 2014. Source apportionment using radiocarbon and organic tracers for PM2. 5 carbonaceous aerosols in Guangzhou, south China: contrasting local-and regional-scale haze events. Environ. Sci. Technol. 48 (20), 12002-12011.

Liu, J.W., Li, J., Ding, P., Zhang, Y.L., Liu, D., Shen, C.D., Zhang, G., 2017. Optimizing isolation protocol of organic carbon and elemental carbon for C-14 analysis using fine particulate samples. Atmos. Environ. 154, 9-19.

Liu, W.J., Jiang, H., Yu, H.Q., 2015. Development of biochar-based functional materials: toward a sustainable platform carbon material. Chem. Rev. 115 (22), 12251-12285.

Mao, J.D., Schmidt-Rohr, K., 2004. Accurate quantification of aromaticity and nonprotonated aromatic carbon fraction in natural organic matter by C-13 solid-state nuclear magnetic resonance. Environ. Sci. Technol. 38 (9), 2680-2684.

Meredith, W., Ascough, P.L., Bird, M.I., Large, D.J., Snape, C.E., Sun, Y., Tilston, E.L., 2012. Assessment of hydropyrolysis as a method for the quantification of black carbon using standard reference materials. Geochem. Cosmochim. Acta 97, 131-147.

Pavuluri, C.M., Kawamura, K., Uchida, M., Kondo, M., Fu, P.Q., 2013. Enhanced modern carbon and biogenic organic tracers in Northeast Asian aerosols during spring/ summer. J. Geophys. Res. Atmos. 118 (5), 2362-2371.

Rocha, J.D., Luengo, C.A., Snape, C.E., 1999. The scope for generating bio-oils with relatively low oxygen contents via hydropyrolysis. Org. Geochem. 30 (12), 1527-1534.

Schwarz, J.P., Holloway, J.S., Katich, J.M., McKeen, S., Kort, E.A., Smith, M.L., Ryerson, T.B., Sweeney, C., Peischl, J., 2015. Black carbon emissions from the bakken oil and gas development region. Environ. Sci. Technol. Lett. 2 (10), 281-285.

Szidat, S., 2009. Atmosphere sources of asian haze. Science 323 (5913), 470-471.

Szidat, S., Bench, G., Bernardoni, V., Calzolai, G., Czimczik, C.I., Derendorp, L., Dusek, U., Elder, K., Fedi, M.E., Genberg, J., Gustafsson, O., Kirillova, E., Kondo, M., McNichol, A.P., Perron, N., Santos, G.M., Stenstrom, K., Swietlicki, E., Uchida, M., Vecchi, R. Wacker, L., Zhang, Y.L., Prevot, A.S.H., 2013. Intercomparison of C-14 analysis of carbonaceous aerosols: EXERCISE 2009. Radiocarbon 55 (2-3), 1496-1509.

Szidat, S., Jenk, T.M., Gäggeler, H.W., Synal, H.-A., Fisseha, R., Baltensperger, U., Kalberer, M., Samburova, V., Reimann, S., Kasper-Giebl, A., 2004a. Radiocarbon ( ${ }^{14}$ C)-deduced biogenic and anthropogenic contributions to organic carbon (OC) of urban aerosols from Zürich, Switzerland. Atmos. Environ. 38 (24), 4035-4044.

Szidat, S., Jenk, T.M., Gaggeler, H.W., Synal, H.A., Fisseha, R., Baltensperger, U., Kalberer, M., Samburova, V., Reimann, S., Kasper-Giebl, A., Hajdas, I., 2004b. Radiocarbon $\left(\mathrm{C}^{14}\right)$-deduced biogenic and anthropogenic contributions to organic carbon (OC) of urban aerosols from Zurich, Switzerland. Atmos. Environ. 38 (24), 4035-4044.

Szidat, S., Jenk, T.M., Gaggeler, H.W., Synal, H.A., Hajdas, I., Bonani, G., Saurer, M., 2004c. THEODORE, a two-step heating system for the EC/OC determination of radiocarbon $\left(\mathrm{C}^{14}\right)$ in the environment. Nucl. Instrum. Methods Phys. Res. Sect. B Beam Interact. Mater. Atoms 223, 829-836.

Szidat, S., Jenk, T.M., Synal, H.A., Kalberer, M., Wacker, L., Hajdas, I., Kasper-Giebl, A., Baltensperger, U., 2006. Contributions of fossil fuel, biomass-burning, and biogenic emissions to carbonaceous aerosols in Zurich as traced by C-14. J. Geophys. Res. Atmos. 111 (D7), 12.

Szidat, S., Ruff, M., Perron, N., Wacker, L., Synal, H.A., Hallquist, M., Shannigrahi, A.S., Yttri, K.E., Dye, C., Simpson, D., 2009. Fossil and non-fossil sources of organic carbon (OC) and elemental carbon (EC) in Goteborg, Sweden. Atmos. Chem. Phys. 9 (5), 1521-1535.

Tripathi, M., Sahu, J.N., Ganesan, P., 2016. Effect of process parameters on production of biochar from biomass waste through pyrolysis: a review. Renew. Sustain. Energy Rev. $55,467-481$.

Wang, G.H., Zeng, Y.S., Yao, J., Qian, Y., Huang, Y., Liu, K., Liu, W., Li, Y., 2013. Source apportionment of atmospheric carbonaceous particulate matter based on the radiocarbon. J. Radioanal. Nucl. Chem. 295 (2), 1545-1552.

Wang, Y., Xu, Y., Chen, Y., Tian, C., Feng, Y., Chen, T., Li, J., Zhang, G., 2016. Influence of different types of coals and stoves on the emissions of parent and oxygenated PAHs from residential coal combustion in China. Environ. Pollut. 212, 1-8.

Watson, J.G., Chow, J.C., Chen, L.-W.A., 2005. Summary of organic and elemental carbon/black carbon analysis methods and intercomparisons. Aerosol Air Qual. Res. 5 (1), 65-102.

Wozniak, A.S., Bauer, J.E., Dickhut, R.M., Xu, L., McNichol, A.P., 2012. Isotopic characterization of aerosol organic carbon components over the eastern United States. J. Geophys. Res. Atmos. 117, 14.

Wurster, C.M., Lloyd, J., Goodrick, I., Saiz, G., Bird, M.I., 2012. Quantifying the abundance and stable isotope composition of pyrogenic carbon using hydrogen pyrolysis. Rapid Commun. Mass Spectrom. 26 (23), 2690-2696.

Wurster, C.M., Saiz, G., Schneider, M.P.W., Schmidt, M.W.I., Bird, M.I., 2013. Quantifying pyrogenic carbon from thermosequences of wood and grass using hydrogen pyrolysis. Org. Geochem. 62, 28-32.

Zencak, Z., Elmquist, M., Gustafsson, O., 2007a. Quantification and radiocarbon source apportionment of black carbon in atmospheric aerosols using the CTO-375 method. Atmos. Environ. 41 (36), 7895-7906.

Zencak, Z., Elmquist, M., Gustafsson, Ö., 2007b. Quantification and radiocarbon source apportionment of black carbon in atmospheric aerosols using the CTO-375 method. Atmos. Environ. 41, 7895-7906.

Zenker, K., Vonwiller, M., Szidat, S., Calzolai, G., Giannoni, M., Bernardoni, V., Jedynska, A.D., Henzing, B., Meijer, H.A.J., Dusek, U., 2017. Evaluation and inter-comparison of oxygen-based OC-EC separation methods for radiocarbon analysis of ambient aerosol particle samples. Atmosphere 8 (11), 21.

Zhang, Y., Huang, R.-J., El Haddad, I., Ho, K.-F., Cao, J.-J., Han, Y., Zotter, P., Bozzetti, C., Daellenbach, K.R., Canonaco, F., Slowik, J.G., Salazar, G.A., Schwikowski, M., Schnelle-Kreis, J., Abbaszade, G., Zimmermann, R., Baltensperger, U., Prévôt, A.S.H., Szidat, S., 2015a. Fossil vs. non-fossil sources of fine carbonaceous aerosols in four Chinese cities during the extreme winter haze episode of 2013. Atmos. Chem. Phys. 15 (3), 1299-1312.

Zhang, Y., Perron, N., Ciobanu, V.G., Zotter, P., Minguillón, M.C., Wacker, L., Prévôt, A.S.H., Baltensperger, U., Szidat, S., 2012. On the isolation of OC and EC and the optimal strategy of radiocarbon-based source apportionment of carbonaceous aerosols. Atmos. Chem. Phys. 12 (22), 10841-10856.

Zhang, Y.L., Liu, D., Shen, C.D., Ding, P., Zhang, G., 2010. Development of a preparation system for the radiocarbon analysis of organic carbon in carbonaceous aerosols in China. Nucl. Instrum. Methods Phys. Res. Sect. B Beam Interact. Mater. Atoms 268 (17-18), 2831-2834.

Zhang, Y.L., Schnelle-Kreis, J., Abbaszade, G., Zimmermann, R., Zotter, P., Shen, R.R., Schafer, K., Shao, L.Y., Prevot, A.S.H., Szidat, S., 2015b. Source apportionment of elemental carbon in beijing, China: insights from radiocarbon and organic marker measurements. Environ. Sci. Technol. 49 (14), 8408-8415.

Zhu, S.Y., Ding, P., Wang, N., Shen, C.D., Jia, G.D., Zhang, G., 2015. The compact AMS facility at Guangzhou Institute of Geochemistry, Chinese academy of sciences. Nucl. Instrum. Methods Phys. Res. B 361, 72-75.

Zhu, Y., Tao, S., Price, O.R., Shen, H.Z., Jones, K.C., Sweetman, A.J., 2015. Environmental distributions of benzo a pyrene in China: current and future emission reduction scenarios explored using a spatially explicit multimedia fate model. Environ. Sci. Technol. 49 (23), 13868-13877.

Zotter, P., Ciobanu, V.G., Zhang, Y.L., El-Haddad, I., Macchia, M., Daellenbach, K.R., Salazar, G.A., Huang, R.-J., Wacker, L., Hueglin, C., Piazzalunga, A., Fermo, P., Schwikowski, M., Baltensperger, U., Szidat, S., Prévôt, A.S.H., 2014. Radiocarbon analysis of elemental and organic carbon in Switzerland during winter-smong episodes from 2008 to 2012 - Part 1: source apportionment and spatial variability. Atmos. Chem. Phys. 14, 13551-13570. 